
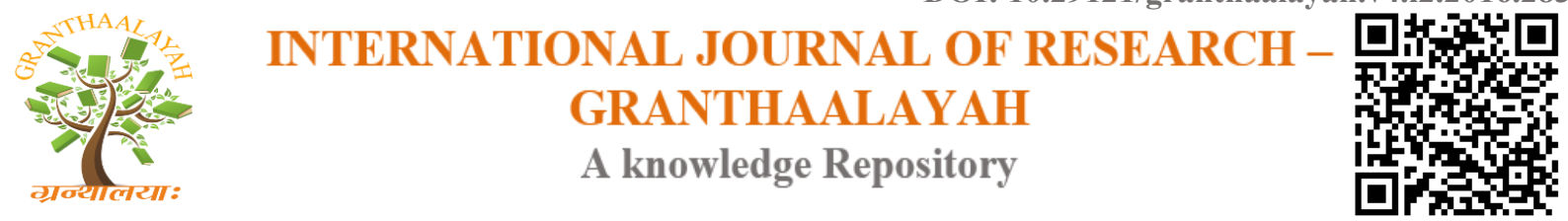

Management

\title{
STOCK MARKET INVESTORS MECHANICS AND THEIR BLUNDERS
}

\author{
Dr. Ravi Kumar ${ }^{1}$, Rohini Sajjan ${ }^{2}$ \\ ${ }^{1}$ Head, Postgraduate Department of Commerce, N. V. Degree College, Gulbarga-585103, \\ INDIA \\ ${ }^{2}$ Assistant Professor, IASMS, Bangalore, INDIA
}

\begin{abstract}
Investment mistakes happen for a multitude of reasons, including the fact that decisions made under conditions of uncertainty that are irresponsibly downplayed by market gurus and institutional spokespersons. Losing money on an investment may not be the result of a mistake, and not all mistakes result in monetary losses. But errors occur when judgment is unduly influenced by emotions, when the basic principles of investing are misunderstood, and when misconceptions exist about how securities react to varying economic, political, and hysterical circumstances. Proper planning and using of techniques, strategies can come as rescue to the investor and help in reaping profits and avoiding the blunders that are commonly observed. The paper investigates the basis for investment patter by the investor, their techniques and strategies adopted and guidelines to be followed to avoid the common blunders made by them leading to fewer losses they would face otherwise.
\end{abstract}

Keywords:

Investors, Strategies, Blunders, Profit, Losses, Stocks.

Cite This Article: Dr. Ravi Kumar, and Rohini Sajjan, "STOCK MARKET INVESTORS MECHANICS AND THEIR BLUNDERS" International Journal of Research - Granthaalayah, Vol. 4, No. 2 (2016): 243-249.

\section{INTRODUCTION}

The stock market is a major part of the financial world. The stock market is a place where investor can generate the huge profit and source of capital for business. This market is a speculative tool of big corporations to collect the average citizen's life savings. The stock market is probably the most important element of investment world. Everyone who is aiming for financial freedom will inevitably face this market; you just need to have a solid understanding of stocks and how they trade on the stock market.

Over the last few decades, the average person's interest in the stock market has grown exponentially. This demand coupled with advances in trading technology has opened up the markets so that now days nearly any individual wants to own stocks. 
Despite their popularity, however, most people don't fully understand stocks behaviour. This makes people to lose their money in stock market. Stocks can create massive amounts of wealth, but they aren't without risks. The only solution to this is education. The key to protecting yourself in the stock market is to understand where you are investing your money.

As it shows that investing in stock market is very risky and as well as high beneficial also, the present study reveal the mechanics adopted by the investors which helped them to make profits/good returns and their blunders that lead to loss.

\section{RELEVANCE OF STUDY}

Investment is a process where the investors invest amount with expectation of good returns and possible assessment of risk at their individual levels. Profit and Losses have been part of the investment due to techniques used, mistakes and blunders made by the investors in the process of investment and this itself makes the present study important.

\section{REVIEW OF LITERATURE}

The Review of literature in the concerned research area is of great importance in carrying out further research work. The research works reviewed here have been sourced from various journals, internet sites, etc.

Peter (1970) carried out a study to identify those factors which motivate or guide the investment decisions of the retail stock investors. The study identified factors such as income from dividends, rapid growth, purposeful investment as a protective outlet of savings and Professional investment management.

Shanmugam (1990) studied a group of 90 investors to examine the factors affecting investment decision. The study focused its analysis on the investment objective and the extent of awareness on factors affecting investment decision. The study found that the Indian investors were high risk takers. The investors possessed adequate knowledge of government regulations, monetary and fiscal policy.

Krishnan and Booker (2002) analyzed the factors influencing the decisions of investors who basically used analysts ${ }^{\text {ee }}$ recommendations to arrive at a short-term decision to hold or to sell a stock.

Best stock solutions (2012) Ignorance may be bliss, but not knowing why your stocks are failing and money is disappearing from your pockets is a long way from paradise. In this article, it uncover some of the more Portfolio mismanagement like, Ignoring Catalysts, Catching the Falling Knife, Failing to Consider Macroeconomic Variables, Not Recognizing Seasonal Fluctuations, Avoiding Technical Trends. as well as they provide the suggestions on how to avoid them.

Joe Budden (2013) analyzed that successful at anything in life it takes dedication and a willingness to learn. But nothing can be as expensive as learning to play or invest in the stock 
market when you don't know what you are doing. Never trade blind, Don't Invest on Tips, Never trade on emotions, never invest all your capital in one thing.

\section{OBJECTIVES OF STUDY}

- To understand the basis of planning for investment preferred by the investors.

- To understand the trading mechanism and strategies of investors.

- To understand common mistakes made by most of the investors.

\section{METHODOLOGY OF THE STUDY}

Descriptive Research Design is planned to be used as research design to the present investigation. Under this method data are collected through field survey. The data is collected by administrating the interview schedule and personal interviews to 30 investors. The present study is planned done through the descriptive method as the study is descriptive and fact finding in nature. Simple random method a Probability based sampling is used as the appropriate method in this study. Among the different methods of Simple Random Sampling, lottery method is chosen to select the sample of investors.

\section{RESULTS AND DISCUSSIONS OF THE STUDY}

\section{BASIS OF PLANNING FOR INVESTMENT PREFERRED BY THE INVESTORS}

- Analyzing the investors experience in the stock market trading it can be stated that the investors above 5 years' experience i-e $29.99 \%$ are conservative investors as they are highly experience, knowledge rich $\&$ analytical competent. They prefer to invest in those companies that extend consistent returns to their investments. Next to above 3 to 5 years \& 1 to 3 years $(19.99 \%$ \& $39.99 \%)$ years experienced investors fall in mix of conservative and aggressive strategy in stock market investments who generate moderate profits with their little experience and knowledge. Lastly less than 1 year $(9.99 \%)$ experienced investors are not generating much profits; they are at risk because of lack of experience and knowledge and are aggressive towards earning profits at the earliest.

- Analyzing the investors, it was found that $53.33 \%$ of investors go for company analysis before investing in stock market to avoid the losses about which investors are unaware and $46.66 \%$ of investors do not go for company analysis as they are dependent upon brokers, news channels and magazines.

- Analysis of data state 50\% of investors go for Industry analysis before investing in stock market as they want to know about various industries and their performance in past periods and understand the industry trends about which the investors are unaware to construct profitable portfolio and $50 \%$ of investors do less Industry analysis as they are dependent upon brokers, news channels and magazines.

- It was found that $63.33 \%$ of investors go for analysis of past performance of Stocks before investing to predict the future move of stock market and avoid the possible losses and $36.66 \%$ of investors do not go for analysis of past performance of Stock before investing in stock as they blindly invest in stock. 
- Investors of $63.33 \%$ are consider high returns as important factor because they are ready to take high risk as they are investing in derivatives, commodities and huge quantity investment in equity, $43.33 \%$ of investors consider safety of principal as important factor as they prefers to invest in mutual funds and $33.33 \%$ of investors consider low risk as they are investing in guilt edge securities.

\section{TRADING MECHANISM AND STRATEGIES OF INVESTORS}

- Studies found that $33.33 \%$ of investors calculate future value of their stock before investing in stock which is important to avoid future losses and $66.66 \%$ of investors do not calculate and blindly invest in stock; most of investors do invest, suggested by others.

- $66.66 \%$ of investors devote their time towards market research to understand the movements better and are aware of the methods of market research and $33.33 \%$ of investors are unaware of methods of market research and also lack time because of their personal commitments and busy schedules and they invest on the basis of suggestion of brokers.

- Of 30 respondents, $16.66 \%$ percent of respondent Prefers to purchase high price shares because they think that high price shares give more returns, $73.33 \%$ percent of respondent prefer to purchase low price shares because they can purchase more number of shares if share price is low and small price movement will give them high margins and 9.99\% percent of respondent prefers to purchase both high as well as low price shares thinking that high or better profits in one stock can compensate loss of others or low expected returns if any

- It is found that $53.33 \%$ of investors consider financial position of the company is an important aspect while selecting shares because if the company is solvent all the other aspects will be preferable, $29.99 \%$ of investors consider dividend payout ratio is an important aspect as they are only consider about dividend and $19.99 \%$ of investors consider past performance as an important aspect because if past performance of stock is good means it will gives good returns. Technical analysis states in its assumptions that the market repeats, so based on that if the past performance $\&$ the company was good then we can expect a good returns in future.

- Experts opinions is also treated as one of the strategy towards effective investment and it is found that $59.99 \%$ of investors take brokers advice or suggestions for investment decision making, 39.99\% of investors seek help from magazines and newspaper to get the information required to take effective investment decision, 19.99\% of investors feel media channels like NDTV profits, Times Now which help them in taking better investment decision and $13.33 \%$ of investors seek advice from Family \& friends as they believe their advice and invest.

- Construction of portfolio is considered to be one of best strategies to stock market investment and it found that $58.06 \%$ of investors construct their portfolio by themselves because they don't want to put themselves into the loss \& to avoid risk for portfolio structured by others and $41.94 \%$ of investors construct their portfolio with the help of Broker/Consultant as they are not aware of constructing of portfolio effectively.

- Monitoring their investment is considered as one of the important trading mechanism and $39.99 \%$ of investor monitor daily as they are intraday traders and they do not invest for long term they monitor their investment daily to check out the performance of their share, 
$26.66 \%$ of investors monitor their investment occasionally these are business people and dependent on brokers, $19.99 \%$ of investors monitor their investment weekly to check out performance of their shares and $13.33 \%$ of investors monitor their investment on monthly basis as these investors are long term investors.

- $83.33 \%$ of investors wait for share prices to rise further before selling as they have hope of earning more profits and $16.66 \%$ of investors do not wait for share prices to rise further because they avoid losses by selling of shares when price rise, as they think this increase leads to the point of resistance by the market and leads to a reversal trend which may put them into losses, if the prices start moving downwards.

\section{COMMON MISTAKES MADE BY MOST OF THE INVESTORS}

- Most of the investors will not do their own research about Company analysis, Industry analysis and past performance of stock. They are dependent on brokers and friends advice.

- Investors believe that higher the risk, higher the return but it does not hold good in all times.

- The over confidence level of the Institutional Investors was also considered as another factor influencing the individual investors as they follow the actions of institutional investors and they will be safer side and individual face losses if even small downside corrections happen in the market movements.

- Investing all the returns they earn back to market without withdrawing the profit part for them is a blunder investors make and time may occur where they may lose both principal and profit money.

- Allowing the brokers to purchase and sell on behalf without correctly looking into the prices prevailing in the market making less scope for better profit and leaving the margin to brokers.

- The distinction between Asset Allocation and Diversification is often clouded. Asset Allocation is the planned division of the portfolio between Equity and Income securities. Diversification is a risk minimization strategy used to assure that the size of individual portfolio positions does not become excessive in terms of various measurements.

- Investors become bored with their Plan too quickly, change direction too frequently, and make drastic rather than gradual adjustments. Although investing is always referred to as "long term", it is rarely dealt with as such by investors who would be hard pressed to explain simple peak-to-peak analysis. Short-term Market Value movements are routinely compared with various un-portfolio related indices and averages to evaluate performance. There is no index that compares with your portfolio, and calendar divisions have no relationship whatever to market or interest rate cycles.

- Investors just don't understand the nature of Interest Rate Sensitive Securities and can't deal appropriately with changes in Market Value... in either direction

- "cheaper is better" mentality weakens decision making capabilities and leads investors to dangerous assumptions and short cuts that only appear to be effective.

- An investment policy not clearly defined: This would also include an unclear view on risk. Here, the investor would be prone to greed and fear as the market goes up and down, respectively. This vacillation would cause the investor much loss and pain. 
- We must clarify at the beginning whether we are doing an investment exercise or are we indulging in ego satisfaction. If it is investment then do the analysis as the markets and the investment instruments will still be there tomorrow. On the other hand, if it is ego satisfaction, then may the Gods bless you, as other would profit from your market actions.

- Another situation could cause the investor a loss of balance. As the market goes up and continues going up, the investor tends to set aside all thoughts on the various investment risks and follows the investing public. Here, the investor is being greedy, and sooner or later would pay the price for this error of judgment.

- Stock Switching is a situation; the investor is selling one stock and at the same time buying another stock. This is interesting, as here the investor expects that the first stock would go down in value, while the second stock would go up. This is unique and is rarely successful.

- Investors are tempted to buy shares of companies that they know and are familiar with. However, the investor should keep in mind, that his knowing a company is not correlated to the returns he expects to derive from his investments in its stock.

- Over diversification and under diversification are also one of mistakes done by the share holders.

\section{CONCLUSION}

The research paper started with an objective of understanding perception of investors towards their investment and pattern and the strategies that they adopt towards their investments. Meanwhile it also try to understand what are the prime aspect or the barriers which investor faced in the investment what where the blunders that they have come across which left out them into problems or loss.

The analysis states that most of the investors construct portfolio by themselves and many of the investors prefer to purchase low price shares were the prime strategies where adopted and of the various blunders over dependent on brokers and not doing own research was the prime blunders which left them to the loss.

To conclude the study it brought out that the investors got in depth knowledge about investment and they tried to understand their pitfalls which let them to the losses and helped them to rectify the same.

\section{REFERENCES}

[1] Bhat Ramesh \& Pandey I M (1987), "Efficient Market Hypothesis : Understanding and Acceptance in India" Indian Institute of Management Ahmedabad, Research and Publication Department in its series IIMA Working Papers with number WP1987-0701_00767.

[2] Shanmugam K (1990). "A Study on Investors" Awareness of Investment”, Ph.D Thesis (Unpublished). Bharathiar University, India

[3] Krishnan R, Booker DM (2002). “Investors Use of Analysts' Recommendations”. Behav. Res. Account., 14: 129-158. 
[4] Hussein A. Hassan Al-Tamimi,(2006)n "Factors influencing Individual Investor Behavior: An Empirical Study of the UAE Financial Market” The Business Review, Cambridge, 01/2006; 5(2):225-232

[5] Bennet.E.et.al.,(2011) "The Influence of Stock-Specific Factors on Investors' Sentiment" World Journal of Social Sciences Vol. 1. No. 4. September 2011. Pp.107-116

[6] A. P. F. Atman, Bruna Amin Gonçalves., "Influence of the Investor's Behavior on the Complexity of the Stock Market" Working paper

[7] Bennet E, Selvam M (2011). "Factors Influencing Retail Investors Attitude towards Investing In Equity Stocks: A Study In Tamil Nadu, J. Modern Account\& Auditing. 7 (3), 316,(2011)

[8] Bennet E, Selvam M (2011). "Investors perception towards the influence of SPERTE" IJMBS Vol. 1, Issue 2, June 2011, ISSN : 2330-9519 (Online)| ISSN : 2231-2463 (Print)

[9] Vivek.N.,(2012)., "The impact of investors' sentiment on the equity market: Evidence from Indian stock market” African Journal of Business Management Vol. 6(32), pp. 9317-9325, 15 August, 2012

[10] http://myinvestingnotes.blogspot.in/2009/10/seven-forehead-slapping-stockblunders.html

[11] E.Gordon \& K.Natarajan, Financial Markets and Services, Himalaya Publications, 2010, ISBN-13-9789351426400

[12] www.bse.com,www.nse.com, www.sebi.com, www.nsdl.co.in/ 